\title{
The Legal Conflicts, the Legislative Vacancies and the Legislative Lags in the Chinese Environmental Legal System
}

\author{
Yue Zhu \\ Graduate School, Chinese Academy of Social Sciences, Beijing, China \\ Email: aeonis@qq.com
}

How to cite this paper: Zhu, Y. (2019). The Legal Conflicts, the Legislative Vacancies and the Legislative Lags in the Chinese Environmental Legal System. Journal of Geoscience and Environment Protection, 7, $12-45$.

https://doi.org/10.4236/gep.2019.73002

Received: February 4, 2019

Accepted: March 5, 2019

Published: March 8, 2019

Copyright (อ 2019 by author(s) and Scientific Research Publishing Inc. This work is licensed under the Creative Commons Attribution International License (CC BY 4.0).

http://creativecommons.org/licenses/by/4.0/

\begin{abstract}
The inconsistency and disharmony in China's environmental legal system are seriously undermining the authority and effectiveness of environmental laws, making it hard to achieve the national environmental legislative goals. It is found in this study that at least 18 administrative regulations and rules conflict with the five recently-revised environmental laws. The legislative vacancy rate of province-level environmental laws reaches $27.8 \%$, and that of city-level environmental laws in the major cities reaches $59.7 \%$. Besides, $66 \%$ of the local including both province-level and city-level environmental laws have the problem of legislative lags, with an average lag of 2547.8 days. In addition, there are many legal conflicts between national environmental laws and local environmental laws. In order to help China to build a harmonious and unified environmental legal system, some suggestions are proposed in this study, including comprehensively examining the lower-level environmental laws, strengthening the leading role of local people's congresses in environmental legislation, improving the construction of filing and review mechanism, and optimizing the mechanisms for information disclosure and public participation.
\end{abstract}

\section{Keywords}

China, The Environmental Legal System, Legal Conflict, Legislative Vacancy, Legislative Lag

\section{Introduction}

Along with China's rapid economic growth, the environment and ecology in China have also been damaged. For many years, China has sacrificed the environment for GDP growth, and environmental protection was not the focus of 
attention for the Chinese government. In the past, the economic growth of China was a relentlessly overriding goal, which could be used to appease the people, absorb elites and strengthen security spending to maintain stability.

However, the increasingly severe ecological and environmental problems have severely affected China's political stability and challenged the ruling legitimacy. Currently, China is facing severe environmental pollution problems. In the 2018 Environmental Performance Index (EPI) ranking, China ranked the $120^{\text {th }}$, an eleven places drop from 2016, reflecting its rapidly deteriorating environment (EPI Team, 2018). When their health and environmental rights were threatened, more and more Chinese citizens began to make their voices heard, including petitions, demonstrations, and marches. Sometimes even large-scale protests against the government and the police occurred, such as massive environmental protests in Xiamen in 2007, Dalian in 2011, Shifang in 2012, and Qidong in 2012, etc. From 2005 to 2012, there were 927 group events directly handled by the Ministry of Environmental Protection, including 72 large-scale events (Yang, 2012). In 2014, there were 37 more-than-one-hundred-people environmental group events (Tian et al., 2014). At least 52 large-scale environmental group events occurred in the first half of 2016, including 12 more-than-one-thousand-people group events (Zhang \& Liu, 2017). Environmental issues have become one of the leading causes of large-scale mass incidents.

In the face of increasing political pressures due to environmental issues, the Chinese government has to acknowledge in "China's 13th Five Year Plan: Environment" that the core tasks of the government are to improve environmental quality, strengthen comprehensive management of the ecological environment, and make full efforts to complement the short board of ecological environment. In the report of the $19^{\text {th }}$ National Congress of the communist party of China, the communist party of China (the $\mathrm{CPC}$ ) has recognized environmental protection as basic national policy and promised to implement "the strictest environmental protection systems".

However, there is little evidence that the current environmental legal system can effectively improve the environmental quality (Bao et al., 2013). The Chinese legal system seems to have "no big mistakes but also no obvious effects", "everything looks perfect and extensive, but it's difficult to find a specific solution to the problem in the law provisions when facing real problems" (Wang, 2009). As revealed by the Qilian Mountain ecological event in September 2017, an essential reason for the deteriorating environment is the inconsistency and disharmony in the Chinese environmental legal system (The CPC, 2017).

China's national environmental laws are too principled and lack of operability, especially lack of detailed rules on law enforcement and safeguard mechanisms. Moreover, under the current environmental legal system, the province-level and city-level people's congresses and governments mainly play the role of the executives of national environmental laws. At the same time, the $\mathrm{Na}$ tional People's Congress (the NPC) and the central government/the state council 
mainly supervise the local environmental laws enforcement. Thus, the enforcement of the higher-level laws has to rely on the effectiveness of the lower-level laws, including administrative regulations, administrative rules, and local environmental laws (local decrees, local rules, autonomous decrees and special decrees). However, this article found three main problems causing the disharmony of the Chinese environmental legal system based on a contextual analysis of 30 environmental (and natural resource) laws, 43 environmental administrative regulations, 85 environmental administrative rules, and 2908 environmental local decrees, local rules, autonomous decrees and special decrees. The first is the legal conflicts between the recently-revised national environmental laws and lower-level environmental administrative regulations and administrative rules. The second is the legislative vacancies and legislative lags in local environmental laws. The third is the legal conflicts between national environmental laws and local environmental decrees and rules.

According to Article 4 of the Legislation Law of China, the unity of the socialist legal system is one of the basic principles of the Chinese legislation. It requires that lower-level laws shall not conflict with higher-level laws. However, this principle does not prohibit the legal conflicts between the same level laws. According to the principle of unity, on the one hand, administrative regulations and rules shall not conflict with higher-level laws. On the other hand, local laws are not allowed to contradict the Chinese constitution, higher-level laws, and administrative regulations.

Specifically, the principle of unity can be divided into the following sub-principles. Firstly, lower-level legislation must strictly follow the procedures within its statutory legislative authority, and avoid interference from departmentalism and local protectionism. Secondly, local decrees shall not contravene any provision of the Chinese Constitution, national laws and administrative regulations, according to Article 72, Paragraph 2, of Legislation Law. In particular, according to Article 72, Paragraph 2, of Legislation Law, and Article 12 of Administrative License Law, no administrative penalties and administrative licenses shall be created in any other local decrees without the authority from higher-level laws. Thirdly, without any basis in laws, administrative regulations, or local decrees, no local rules can be authorized to set out any requirements that impair the rights or increase the obligations of citizens, legal persons, and other organizations. Fourthly, given the fact that the implementation of a higher-level law relies on the more specific and operational lower-level laws, lower-level legislation should avoid legal lags behind higher-level laws; otherwise the former will be difficult to be implemented. At present, the status quo of the inconsistency in the Chinese environmental legal system seriously violates Legislation Law, undermines the authority and effectiveness of national environmental laws, and makes it even harder to implement the national environmental laws.

Through a brief review of the relevant studies on the Chinese environmental legal system, it is found that many published research papers on this issue supported the view stated above. Most of the previous studies on local environmen- 
tal laws based upon the empirical analyses on the status quo of several provinces or a certain province. Zeng (2015) proposed that the problems existing in China's local environmental laws mainly include the low legislative authority, the local protectionism and the absence of public participation. Wan (2018) pointed out through an empirical analysis that the overlapping local laws, the lack of local characteristics, the legal conflicts, and the unscientific punishment system weakened the effectiveness of local environmental laws. Li and Sheng (2018) analyzed the relationship between local environmental laws and the efficiency of industrial resource allocation in the manufacturing industry. They concluded that such a relationship has the function of optimizing resource allocation. $\mathrm{Li}$ (2016) argued that the current local environmental laws still have many problems, such as the low quality of local laws, the legislative lags, the departmental and local protectionism, and the imperfect legislative procedures. Wang (2010) took Henan Province, Shanxi Province, Hubei Province, Anhui Province, Hunan Province and Jiangxi Province as examples, and identified a negative correlation between the GDP growth and the yearly number of the revisions (and abolitions) of local environmental laws. Some researchers focused on the local environmental laws in a specific province, such as Shanxi province (Li, 2014), Jiangsu province (Zang, 2015), Guangdong province (Li, 2017), Hebei province (Yang, 2010), Liaoning province (Jin, 2011), Guangxi Zhuang autonomous region (Jiang \& Liang, 2008), and Shandong province (Wang \& Wang, 2018), etc. All studies on a specific province found and highlighted the legal conflicts, the legislative vacancies and legislative lags existing in China's local environmental laws.

Meanwhile, many studies attached importance to the relationship and conflicts between national environmental laws and local environmental laws. Feng (2016) argued that, in reality, the local legislatures had the problems such as the lack of legislative experts, the insufficient legislative mechanism, the absence of public participation, and the severe local protectionism, etc. Zhou (2018) argued that there were some defects in the allocation of legislative powers related to environmental protection between national and local legislatures at present, causing problems such as the over lapping local laws, the legislative lags, and the legal conflicts. The above studies conclusively presented the legal conflicts and the legislative lags between national environmental laws and local environmental laws.

In addition, this view is supported by some comparative studies on Chinese local environmental laws and foreign local environmental laws. Wang (2009) conducted a comparative study on the local environmental laws between China and the United States. He argued that China's local environmental legislation still remained at a relatively primary stage in contrast with the United States'. Guo and Huang (2005) compared the local environmental laws between China and Australia and found that Australia's local laws in were more specific and operational than China's. Wang (2014) compared the legislative models of envi- 
ronmental criminal law between China and the United States, Japan, Germany, and France. Yuan (2018) compared the laws related to the environmental information disclosure between the Chinese and European governments and concluded that China should learn from the EU. Collectively, these studies outlined that Chinese environmental legal systems were far behind those in western countries, and one of the major reasons was the inconsistency.

However, none of the studies reviewed above ever investigated the inconsistency of China's environmental legal system from a holistic perspective. For this reason, this article attempts to reveal the disharmony in China's environmental legal system and propose suggestions based on the comprehensive analysis of 30environmental and natural resource laws, 45 environmental administrative regulations, 85 environmental administrative rules, and 2908 environmental local decrees, local rules, autonomous decrees and special decrees. The first section briefly introduces China's existing environmental legal system. The second section discusses the legal conflicts between the recently-revised national environmental laws and the lower environmental administrative regulations and rules. The third section discusses the legislative vacancies and the legislative lags in China's local environmental laws. The fourth section discusses the legal conflicts between national environmental laws and local laws. It should be pointed out that the inconsistency is not the only reason for the invalidation of China's environmental legal system. As many studies have pointed out, the one-party dictatorship of the CPC, the unscientific environmental legislative procedure at the national level, the lack of environmental awareness in local governments, and the absence of an effective environmental litigation system are also important reasons for China's increasingly serious environmental problems (Xu \& Faure 2016).

\section{Overview of the Chinese Environmental Legal System}

In September 1979, the $11^{\text {th }}$ NPC promulgated Environmental Protection Law (Tria), marking the beginning of the construction of China's environmental legal system. From 1979 onwards, the development of environmental law in China can be divided into three stages. The first stage started with the promulgation of Environmental Protection Law (tria) in 1979 and ended with the enforcement of Environmental Protection Law in 1989, marking the gradual formation of the Chinese environmental legal system. During this period, China promulgated a number of special environmental laws, such as Marine Environmental Protection Law (1982), Law on Prevention and Control of Water Pollution (1984), Forest Law (1984), Law on the Prevention and Control of Atmospheric Pollution (1987), and Environmental Protection Law (1989). The second stage is from 1989 to 2012, and the environmental legal system was further improved. More special laws, such as Cleaner Production Promotion Law, Renewable Energy Law and Law on Evaluation of Environmental Effects, etc., were promulgated as the sign that the Chinese environmental legal system was basically formed. At the same time, China carried out extensive international exchanges and cooperation 
in environmental protection, and acceded to a series of international environmental conventions. The third stage is from 2013 to now. Due to the aggravation of ecological problems, the CPC has decided to change the long-term economic development model featuring high pollution, high energy consumption and high investment, and declared that it will stick to the green, low-carbon and circular development model and give priority to environmental protection in its national development strategy. The Chinese Constitutional Amendment in 2018 adds "ecological civilization" into the preamble, includes "to direct and administer environmental development" as one of the functions and powers of the State Council in Article 89, shedding new light on environmental protection in China. Environmental Protection Law, comprehensively amended in 2014, has included "protect the public health" as a general principle (Article 1), and widened standing for environmental public interest litigation (Article 58). In addition, the environment has become a general principle for civil activities, with Article 9 of the General Rules of the Civil Law, enacted in 2017, stating that "any civil activity conducted by civil subjects shall be conducive to saving resources and protecting the ecological environment." During this period, a progress has been made through the interaction of legislation and revisions, building up a consistent and cohesive framework to tackle the environmental problem.

China's current environmental legal system is based on Environmental Protection Law, including the special laws about environmental pollution control, ecological conservation, resources, energy conservation and recycling, environmental damage liability, environmental impact assessments and other spheres. In addition to international treaties, China's environmental legal system can be divided into national environmental laws and local environmental laws; the former includes environmental laws promulgated by the NPC or its standing committee, administrative regulations promulgated by the State Council, and administrative rules promulgated by ministries and commissions; the latter includes local decrees, autonomous decrees and special decrees issued by local people's congresses, local rules issued by local governments.

So far the Ministry of Ecology and Environment and the legislative branches have not clarified the scope and directory of China's environmental legal system except the directory of environmental administrative rules. This article argues that a law can be classified into the environmental legal system if it follows two principles. On the one hand, its legislative purposes should be in accordance with Article 1 of Environmental Protection Law, "protecting and improving the environment" and "preventing pollution and other public hazards". On the other hand, its legal interests should be mainly the "environmental benefits". Besides, given that the natural resources laws are closely related to environmental laws, the two are generally referred to as the environmental legal system in a broad sense or "the environmental and natural resources legal system". Based on the two principles above, this article has found that China's environmental (and natural resources) legal system includes 30 laws, 45 administrative regulations, 
85 administrative rules, and 2908 local decrees, local rules, autonomous decrees and special decrees.

Meanwhile, China has preliminarily formed a relatively orderly environmental judicial system and a moderately effective environmental trial mechanism. According to 2018 Supreme People's Court work report, from January 1, 2013, to December 31, 2017, about 88,000 criminal cases on environmental and natural resources were concluded, accounting for $1.6 \%$ of all criminal cases; about 487,000 civil and administrative cases on environmental and natural resources were concluded, accounting for 3\% of all civil cases, and 1635 cases of environmental public interest litigation were concluded. Since 2013, the number of environmental cases has been growing at an average annual rate of $8.3 \%$. China's Environmental Justice Development Report (2015-2017) shows that, as of April 2017, the People's Courts of 31 provinces, municipalities, and autonomous regions set up 946 special judicial organs for cases of environmental and natural resources, including 296 divisions, 617 collegial panels and 33 circuit courts.

\subsection{Synopsis of China's National Environmental Laws}

China's national environmental laws in force include 29 national laws, 45 administrative regulations, and 85 administrative rules.

As of October 1, 2018, as shown in Table 1, the NPC and its standing committee has promulgated 19 environmental laws, accounting for $7 \%$ of 270 laws in force. According to "China Judgment online", from 1 January, 2013, to 31 December, 2017, the 19 laws were cited in 7669 related judgments (average 1576 judgments per year). ${ }^{1}$ Among them, there were 4833 first-instance judgments (63.8\%), 2762 second-instance judgments (35.2\%), and 74 retrial judgments (0.9\%). The most-cited law is Environmental Protection Law, with a total of 3349 judgments. Law on Prevention and Control of Water Pollution comes second, with 1254 judgments. The third one is Law on the Prevention and Control of Atmospheric Pollution, with 645 judgments. In addition to the three laws enacted after 2016, Cleaner Production Promotion Law, Law on the prevention and control of radioactive pollution, Renewable Energy Law, Law on the Protection of Offshore Islands, and Law on Prevention and Control of Desertification are rarely cited.

As shown in Table 2, the NPC and its standing committee has promulgated 10 natural resources laws. From 1 January, 2013, to 31 December, the 10 laws were cited in 118,327 related judgments (average 23,665 judgments per year). The most cited one is Land Administration Law, with 84,913 judgments. The number of natural resource cases is far higher than that of environmental protection cases, indicating that the current focus of environmental justice is on the utilization rather than protection.

${ }^{1}$ How do we know the number of judgements of an environmental law? Firstly, go to "China judgements online" and select "advanced search". Secondly, enter the name of the environmental law in the "legal basis" field and click search. 
Table 1. The Chinese national environmental laws and related judgments.

\begin{tabular}{|c|c|c|c|c|c|}
\hline Law & $\begin{array}{l}\text { Date of the } \\
\text { Promulgation or } \\
\text { the Last Revision }\end{array}$ & $\begin{array}{l}\text { The } \\
\text { Judgment } \\
\text { of First } \\
\text { Instance }\end{array}$ & $\begin{array}{l}\text { The } \\
\text { Judgment } \\
\text { of Second } \\
\text { Instance }\end{array}$ & $\begin{array}{l}\text { The } \\
\text { Judgment } \\
\text { of Retrial }\end{array}$ & Total \\
\hline $\begin{array}{l}\text { 1) Law on the Prevention and } \\
\text { Control of Soil Pollution }\end{array}$ & $31 / 08 / 2018$ & 0 & 0 & 0 & 0 \\
\hline $\begin{array}{l}\text { 2) Environmental Protection } \\
\text { Tax Law }\end{array}$ & $25 / 12 / 2016$ & 0 & 0 & 0 & 0 \\
\hline $\begin{array}{l}\text { 3) Law on Evaluation of } \\
\text { Environmental Effects }\end{array}$ & $02 / 07 / 2016$ & 0 & 0 & 0 & 0 \\
\hline $\begin{array}{l}\text { 4) Law on Prevention and } \\
\text { Control of Desertification }\end{array}$ & $31 / 08 / 2001$ & 10 & 3 & 0 & 13 \\
\hline $\begin{array}{l}\text { 5) Law on the Protection of } \\
\text { Offshore Islands }\end{array}$ & $26 / 12 / 2009$ & 9 & 5 & 0 & 14 \\
\hline 6) Renewable Energy Law & $26 / 12 / 2009$ & 11 & 3 & 0 & 14 \\
\hline $\begin{array}{l}\text { 7) Law on the Prevention and } \\
\text { Control of Radioactive Pollution }\end{array}$ & $28 / 06 / 2003$ & 12 & 7 & 0 & 19 \\
\hline $\begin{array}{l}\text { 8) Cleaner Production } \\
\text { Promotion Law }\end{array}$ & $29 / 02 / 2012$ & 10 & 9 & 1 & 20 \\
\hline 9) Meteorology Law & $07 / 11 / 2016$ & 60 & 18 & 0 & 78 \\
\hline $\begin{array}{l}\text { 10) Marine Environmental } \\
\text { Protection Law }\end{array}$ & $04 / 11 / 2017$ & 47 & 46 & 2 & 95 \\
\hline $\begin{array}{l}\text { 11) Law on Water and Soil } \\
\text { Conservation }\end{array}$ & $25 / 12 / 2010$ & 123 & 56 & 13 & 192 \\
\hline 12) Law on Energy Conservation & $02 / 07 / 2016$ & 229 & 27 & 0 & 256 \\
\hline $\begin{array}{l}\text { 13) Circular Economy } \\
\text { Promotion Law }\end{array}$ & $29 / 08 / 2008$ & 222 & 72 & 1 & 295 \\
\hline $\begin{array}{l}\text { 14) Law on the Prevention and } \\
\text { Control of Environmental } \\
\text { Pollution by Solid Waste }\end{array}$ & $07 / 11 / 2016$ & 304 & 98 & 1 & 403 \\
\hline $\begin{array}{l}\text { 15) Law on the Protection } \\
\text { of Wild Life }\end{array}$ & $02 / 07 / 2016$ & 387 & 40 & 0 & 427 \\
\hline $\begin{array}{l}\text { 16) Law on Prevention and } \\
\text { Control of Pollution from } \\
\text { Environmental Noise }\end{array}$ & $29 / 10 / 1996$ & 399 & 190 & 6 & 595 \\
\hline $\begin{array}{l}\text { 17) Law on the Prevention and } \\
\text { Control of Atmospheric Pollution }\end{array}$ & $29 / 08 / 2015$ & 365 & 277 & 3 & 645 \\
\hline $\begin{array}{l}\text { 18) Law on Prevention and } \\
\text { Control of Water Pollution }\end{array}$ & $28 / 02 / 2008$ & 726 & 514 & 14 & 1254 \\
\hline $\begin{array}{l}\text { 19) Environmental } \\
\text { Protection Law }\end{array}$ & $24 / 04 / 2014$ & 1919 & 1397 & 33 & 3349 \\
\hline Total & & 4833 & 2762 & 74 & 7669 \\
\hline
\end{tabular}


Table 2. China's natural resources laws and related judgments.

\begin{tabular}{|c|c|c|c|c|c|}
\hline Law & $\begin{array}{l}\text { Date of the } \\
\text { Promulgation or } \\
\text { the Last Revision }\end{array}$ & $\begin{array}{l}\text { The } \\
\text { Judgment } \\
\text { of First } \\
\text { Instance }\end{array}$ & $\begin{array}{l}\text { The } \\
\text { Judgment } \\
\text { of Second } \\
\text { Instance }\end{array}$ & $\begin{array}{l}\text { Judgment } \\
\text { of Retrial }\end{array}$ & Total \\
\hline $\begin{array}{l}\text { 1) Law on the Exclusive } \\
\text { Economic Zone and the } \\
\text { Continental Shelf }\end{array}$ & $26 / 06 / 1998$ & 0 & 0 & 0 & 0 \\
\hline $\begin{array}{l}\text { 2) Law on the Exploration and } \\
\text { Development of Resources in } \\
\text { Deep Seabed Areas }\end{array}$ & $26 / 02 / 2016$ & 0 & 0 & 0 & 0 \\
\hline $\begin{array}{l}\text { 3) Law on the Territorial Sea and } \\
\text { the Contiguous Zone }\end{array}$ & $25 / 02 / 1992$ & 5 & 0 & 0 & 5 \\
\hline 4) Law on the Coal Industry & $07 / 11 / 2016$ & 138 & 123 & 11 & 272 \\
\hline 5) Grassland Law & $29 / 06 / 2013$ & 676 & 212 & 19 & 907 \\
\hline $\begin{array}{l}\text { 6) Law on the Administration } \\
\text { of the Use of Sea Areas }\end{array}$ & $27 / 10 / 2001$ & 568 & 385 & 34 & 987 \\
\hline 7) Fisheries Law & $27 / 08 / 2009$ & 850 & 420 & 8 & 1278 \\
\hline 8) Water Law & $02 / 07 / 2016$ & 1177 & 774 & 46 & 1997 \\
\hline 9) Mineral Resources Law & $29 / 08 / 1996$ & 3139 & 2211 & 164 & 5514 \\
\hline 10) Forest Law & $29 / 04 / 1998$ & 18052 & 4244 & 158 & 22454 \\
\hline 11) Land Administration Law & $28 / 08 / 2004$ & 46097 & 37352 & 1464 & 84913 \\
\hline Total & & 70,702 & 45,721 & 1904 & 118,327 \\
\hline
\end{tabular}

As shown in Table 3, the State Council has promulgated 45 environmental protection administrative regulations. From 1 January, 2013, to 31 December, 2017, the 45 administrative regulations were cited in 6326 judgments (average 1265 judgments per year). Among them, there are 3733 first-instance judgments, 2534 second-instance judgments, and 59 retrial judgments. Besides, ministries and commissions of the State Council have promulgated 85 environmental administrative rules (Environmental Protection Department, 2016).

The total number of judgments that cited laws and administrative regulations was 132,322 , accounting for only $27.7 \%$ of the entire civil and administrative environmental cases. It can be concluded that, except for environmental criminal cases, the Chinese judges trended to apply environmental administrative rules and local environmental laws to most of the environmental cases. If there are conflicts between higher-level laws and the lower environmental administrative rules and local environmental laws, the legislative goal of the higher-level laws cannot be achieved.

\subsection{Synopsis of the Chinese Local Environmental Laws}

As of 1 October, 2018, based on the principles mentioned above, the local people's congresses and governments have enacted 2908 environmental local decrees, local rules, autonomous decrees and special decrees, accounting for 
Table 3. Administrative regulations and the number of related judgments.

\begin{tabular}{|c|c|c|c|c|c|}
\hline Administrative Regulations & $\begin{array}{l}\text { Date of the } \\
\text { Promulgation or } \\
\text { the Last Revision }\end{array}$ & $\begin{array}{c}\text { The Judgment } \\
\text { of First } \\
\text { Instance }\end{array}$ & $\begin{array}{c}\text { The Judgment } \\
\text { of Second } \\
\text { Instance }\end{array}$ & $\begin{array}{l}\text { The } \\
\text { Judgment } \\
\text { of Retrial }\end{array}$ & Total \\
\hline $\begin{array}{l}\text { 1) Regulations on the National } \\
\text { Pollution Source Survey }\end{array}$ & 09/10/2007 & 0 & 0 & 0 & 0 \\
\hline $\begin{array}{l}\text { 2) Regulations on } \\
\text { Chinese-foreign Cooperation in } \\
\text { Exploiting Continental } \\
\text { Petroleum Resources }\end{array}$ & $18 / 7 / 2018$ & 0 & 0 & 0 & 0 \\
\hline $\begin{array}{l}\text { 3) Civil Nuclear Safety } \\
\text { Equipment Supervision and } \\
\text { Administration Regulations }\end{array}$ & $11 / 07 / 2007$ & 0 & 0 & 0 & 0 \\
\hline $\begin{array}{l}\text { 4) Implementing Method of } \\
\text { Regulations on the Protection } \\
\text { of New Plant Varieties }\end{array}$ & $31 / 12 / 2011$ & 0 & 0 & 0 & 0 \\
\hline $\begin{array}{l}\text { 5) Safety Management of } \\
\text { Radioactive Waste Regulations }\end{array}$ & $20 / 12 / 2011$ & 0 & 0 & 0 & 0 \\
\hline $\begin{array}{l}\text { 6) Regulations on the } \\
\text { Administration of Collection } \\
\text { and Use of Sewage Discharge Fee }\end{array}$ & $02 / 01 / 2003$ & 0 & 0 & 0 & 0 \\
\hline $\begin{array}{l}\text { 7) Regulations on the Emergency } \\
\text { Management of Nuclear } \\
\text { Accident of Nuclear Power } \\
\text { Station }\end{array}$ & 08/01/2011 & 0 & 0 & 0 & 0 \\
\hline $\begin{array}{l}\text { 8) Regulations on the Prevention } \\
\text { and Control of Marine } \\
\text { Environmental Pollutions by } \\
\text { Land Source Pollutants }\end{array}$ & $22 / 06 / 1990$ & 0 & 0 & 0 & 0 \\
\hline $\begin{array}{l}\text { 9) Regulations on Control of } \\
\text { Nuclear Material }\end{array}$ & $15 / 06 / 1987$ & 0 & 0 & 0 & 0 \\
\hline $\begin{array}{l}\text { 10) Implementing Method of } \\
\text { Regulations on Control } \\
\text { Overdamping of Wastes } \\
\text { in the Ocean }\end{array}$ & $08 / 01 / 2016$ & 0 & 0 & 0 & 0 \\
\hline $\begin{array}{l}\text { 11) Regulations on Management } \\
\text { of Waste Electrical and Electronic } \\
\text { Products Recycling }\end{array}$ & $25 / 02 / 2009$ & 1 & 1 & 0 & 2 \\
\hline $\begin{array}{l}\text { 12) Provisional Regulations on } \\
\text { the Prevention and Control of } \\
\text { Water Pollution in the } \\
\text { Huaihe River Basin }\end{array}$ & 08/01/2011 & 1 & 1 & 0 & 2 \\
\hline $\begin{array}{l}\text { 13) Regulations on Foreign } \\
\text { Cooperation in Exploitation of } \\
\text { Offshore Oil Resources }\end{array}$ & 08/01/2011 & 1 & 1 & 0 & 2 \\
\hline $\begin{array}{l}\text { 14) Regulations on Management } \\
\text { of Ozone-Depleting Substances }\end{array}$ & $08 / 04 / 2010$ & 2 & 0 & 0 & 2 \\
\hline $\begin{array}{l}\text { 15) Regulations on Safety } \\
\text { Management of Radioactive } \\
\text { Goods Transportation }\end{array}$ & $14 / 09 / 2009$ & 1 & 1 & 0 & 2 \\
\hline
\end{tabular}




\section{Continued}

16) Regulations on Safety Supervision and Management

29/10/1986

2

$0 \quad 3$

of Civil Nuclear Facilities

17) Regulations on Control

Overdumping of Wastes

08/01/2011

in the Ocean

18) Regulations on Energy

Conservation in Public

$01 / 08 / 2008$

$0 \quad 4$

Institutions

19) Regulations on Protection of Meteorological Facilities and Meteorological observation

$29 / 08 / 2012$

3

1

$0 \quad 4$

Environment

20) Regulations on Water Supply Management of South-to-North Water Diversion

$16 / 02 / 2014$

2

2

0

21) Hydrology Regulations

$25 / 04 / 2007$

3

2

$0 \quad 5$

22) Regulations on the

Prevention and Control of

Vessel-induced Pollution to the

09/09/2009

3

2

Marine Environment

23) Regulations on Management of Taihu Basin

07/09/2011

3

2

$0 \quad 5$

24) Regulations on the Control of Pollution Damage to Marine

Environment in Coastal

25/09/2007

3

3

$0 \quad 6$

Engineering Construction

Projects

25) Regulations on Import and Export of Endangered Wild Fauna and Flora

26) Regulations of Environmental Impact Assessment of Planning

$17 / 08 / 2009$

27) Regulations on Safety

Management and Protection

of Radioisotope and

$14 / 09 / 2005$

5

Radiation Equipment

28) Implementing Method of Law on Prevention and Control of Water Pollution

29) Provisional Regulations of Resource Tax

$30 / 09 / 2011$

13

14

7

0

21

30) Regulations on Farmland and Water Conservancy

$17 / 05 / 2016$

$0 \quad 23$

31) Regulations on Urban

Drainage and Sewage Treatment

$02 / 10 / 2013$

38

22

$1 \quad 61$ 


\section{Continued}

32) Regulations on the

Management of Hazardous Waste

Business Licenses

33) Regulations on the Protection of Mine Geological Environment

34) Medical Waste Management Regulations

35) Regulations on Scenic Spots

36) Regulations on the Prevention of Meteorological Disasters

37) Regulations on Energy

Conservation of Civil Buildings

38) Regulations on Nature

Reserves

39) Regulations on the Prevention and Control of Pollution from Livestock and Poultry Scale Breeding

40) Regulations on the Protection of New Plant Varieties

41) Regulations on the Urban Appearance and Environmental Hygiene Management

42) Regulations on the Urban

Gas Management

43) Pesticide Management Regulations

44) Regulations on Safety

Management of Hazardous

Chemicals

45) Regulations on

Environmental Protection

Management of Construction

Projects

Total
$30 / 05 / 2004$

48

19

68

08/01/2016

61

08/01/2011

19/09/2006

80

$27 / 01 / 2010$

98

01/08/2008

138

08/01/2011

160

$11 / 11 / 2013$

241

118

0

359

$31 / 01 / 2013$

247

147

5

399

08/01/2011

381

197

5

583

$19 / 11 / 2010$

369

316

5

690

$16 / 03 / 2017$

427

325

11

763

$02 / 03 / 2011$

510

280

16

806

16/07/2017

763

722

1494

3733

2534

59

6326

$12.7 \%$ of the total number of local laws in China. As Table 4 shows, among them, there are 1689 local decrees (58.1\%), 986 local rules (33.9\%), and 233 autonomous decrees and special decrees $(8 \%)$.

\section{The Legal Conflicts between the Recently-Revised Environmental Laws and the Lower Administrative Regulations and Rules}

Since Xi Jinping took power in 2012, the major environmental laws have been 
Table 4. Number of the Chinese local environmental laws, distributed by type and provincial administrative region.

\begin{tabular}{|c|c|c|c|c|}
\hline $\begin{array}{c}\text { Provincial } \\
\text { Administrative Region }\end{array}$ & $\begin{array}{l}\text { Local } \\
\text { Decree }\end{array}$ & $\begin{array}{l}\text { Local } \\
\text { Rules }\end{array}$ & $\begin{array}{l}\text { Autonomous Decrees and } \\
\text { Special Decrees }\end{array}$ & Total \\
\hline Beijing & 20 & 14 & 0 & 34 \\
\hline Tianjin & 21 & 22 & 0 & 43 \\
\hline Hebei Province & 62 & 58 & 8 & 128 \\
\hline Shanxi Province & 68 & 15 & 0 & 83 \\
\hline $\begin{array}{l}\text { The Inner Mongolia } \\
\text { Autonomous Region }\end{array}$ & 54 & 26 & 15 & 95 \\
\hline Liaoning Province & 78 & 58 & 15 & 151 \\
\hline Jilin Province & 62 & 29 & 14 & 105 \\
\hline Heilongjiang Province & 76 & 25 & 5 & 106 \\
\hline Shanghai & 14 & 33 & 0 & 47 \\
\hline Jiangsu Province & 105 & 58 & 0 & 163 \\
\hline Zhejiang Province & 80 & 58 & 1 & 139 \\
\hline Anhui Province & 87 & 38 & 0 & 125 \\
\hline Fujian Province & 60 & 27 & 0 & 87 \\
\hline Jiangxi Province & 52 & 15 & 0 & 67 \\
\hline Shandong Province & 111 & 78 & 0 & 189 \\
\hline Henan Province & 43 & 39 & 0 & 82 \\
\hline Hubei Province & 42 & 38 & 10 & 90 \\
\hline Hunan Province & 44 & 16 & 10 & 70 \\
\hline Guangdong Province & 106 & 70 & 3 & 179 \\
\hline $\begin{array}{l}\text { Guangxi Zhuang } \\
\text { Autonomous Region }\end{array}$ & 34 & 16 & 6 & 56 \\
\hline Hainan Province & 43 & 11 & 2 & 56 \\
\hline Chongqing & 28 & 15 & 2 & 45 \\
\hline Sichuan Province & 51 & 36 & 25 & 112 \\
\hline Guizhou Province & 35 & 33 & 21 & 89 \\
\hline Yunnan & 80 & 20 & 38 & 138 \\
\hline Tibet Autonomous Region & 21 & 11 & 0 & 32 \\
\hline Shaanxi Province & 55 & 21 & 0 & 76 \\
\hline Gansu Province & 55 & 34 & 12 & 101 \\
\hline Qinghai Province & 28 & 24 & 36 & 88 \\
\hline $\begin{array}{c}\text { Ningxia Hui } \\
\text { Autonomous Region }\end{array}$ & 41 & 22 & 0 & 63 \\
\hline $\begin{array}{c}\text { Xinjiang Uygur } \\
\text { Autonomous Region }\end{array}$ & 33 & 26 & 10 & 69 \\
\hline Total & 1689 & 986 & 233 & 2908 \\
\hline
\end{tabular}


revised, such as Law on the Prevention and Control of Environmental Pollution by Solid Waste, Environmental Protection Law, Law on the Prevention and Control of Atmospheric Pollution, Law on Evaluation of Environmental Effects, Law on Prevention and Control of Water Pollution, and Law on the Prevention and Control of Environmental Pollution by Solid Waste, etc. The environmental administrative regulations and rules shall be in harmony with the higher-level environmental laws, which is the basic premise and important guarantee for maintaining the unification of the environmental legal system and promoting the construction of ecological civilization. As stipulated in Legislation Law, environmental administrative regulations and rules should not conflict with the higher-level laws. However, in reality, due to the joint influences of departmental and local protectionism, the one-sided emphasis on economic development, and the lack of environmental concern, some provisions of lower-level environmental administrative regulations and rules conflict with higher-level environmental laws. The judicial statistics data above have shown that a large number of judgments are made following administrative regulations and rules. Those legal conflicts have severely damaged the authority and unity of the environmental legal system, and have serious negative impact on the current environmental protection in China. As Table 5 shows, at least 18 administrative regulations and rules conflict with the five recently-revised environmental laws.

\subsection{The Legal Conflicts between Environmental Protection Law and the Relevant Administrative Regulations and Rules}

Environmental Protection Law was revised on 24 April, 2014, and implemented as of 1 January, 2015. The article finds that one administrative regulations and seven administrative rules conflict with the Law.

1) Regulations on the Administration of the Collection and Use of Sewage Charges. The administrative regulations were approved by the State Council and passed on 30 January, 2002. The primary legal conflict is that Article 45 of Environmental Protection Law establishes a sewage permission system and no longer imposes sewage charges on undocumented sewage, which has abolished the basis of the regulations.

2) The following three administrative rules in the chemical industry: Regulations on Environmental Protection Monitoring in Chemical Industry, which was promulgated by the Ministry of Chemical Industry on 31 October, 1988. Regulations on the Environmental Protection Administration of the Chemical Industry, which was promulgated by the Ministry of Chemical Industry on 21 December, 1990. Some Regulations on Environmental Pollution Prevention and Control in the Production and Construction of Chromium Compounds, which was issued by the Ministry of Chemical Industry on 5 May, 1992. The primary legal conflicts are that, on the one hand, the environmental standards set by the three Regulations are entirely different from the new environmental standards, such as Emission Standards of Pollutants for Inorganic Chemical Industry, Emission Standard of Pollutants for Petroleum Chemistry, Emission Standards 
Table 5. The legal conflicts between the recently-revised five environmental laws and the lower-level administrative regulations and rules.

\begin{tabular}{|c|c|c|}
\hline $\begin{array}{l}\text { The national } \\
\text { law }\end{array}$ & The lower-level law & $\begin{array}{l}\text { The primary legal } \\
\text { conflict }\end{array}$ \\
\hline \multirow{8}{*}{$\begin{array}{l}\text { Environmental } \\
\text { Protection } \\
\text { Law }\end{array}$} & $\begin{array}{l}\text { 1) Regulations on the Administration of the } \\
\text { Collection and Use of Sewage Charges }\end{array}$ & these wage charges \\
\hline & $\begin{array}{l}\text { 2) Regulations on Environmental Protection } \\
\text { Monitoring in Chemical Industry; }\end{array}$ & \\
\hline & $\begin{array}{l}\text { 3) Regulations on the Environmental Protection } \\
\text { Administration of the Chemical Industry }\end{array}$ & $\begin{array}{l}\text { the environmental } \\
\text { standards }\end{array}$ \\
\hline & $\begin{array}{l}\text { 4) Some Regulations on Environmental Pollution } \\
\text { Prevention and Control in the Production and } \\
\text { Construction of Chromium Compounds }\end{array}$ & \\
\hline & $\begin{array}{l}\text { 5) Management Measure for Environmental } \\
\text { Protection of Electromagnetic Radiation }\end{array}$ & $\begin{array}{l}\text { the upper limit of } \\
\text { penalties }\end{array}$ \\
\hline & $\begin{array}{l}\text { 6) Measure for the Procedures of the Legislation of } \\
\text { Environmental Administrative Rules. }\end{array}$ & $\begin{array}{l}\text { the legislative } \\
\text { authority of } \\
\text { environmental } \\
\text { administrative rule }\end{array}$ \\
\hline & $\begin{array}{l}\text { 7) Interim Provisions on the Punishments } \\
\text { against Environmental Violations and } \\
\text { Disciplinary Actions. }\end{array}$ & $\begin{array}{l}\text { the blame-taking } \\
\text { resignation of the } \\
\text { primary officials }\end{array}$ \\
\hline & $\begin{array}{l}\text { 8) Measure for the Environmental } \\
\text { Administrative Punishment }\end{array}$ & $\begin{array}{l}\text { the administrative } \\
\text { penalties }\end{array}$ \\
\hline \multirow{2}{*}{$\begin{array}{l}\text { Law on } \\
\text { Evaluation of } \\
\text { Environmental } \\
\text { Effects }\end{array}$} & $\begin{array}{l}\text { 1) Measure for Environmental Protection } \\
\text { Management of Traffic Construction Projects }\end{array}$ & $\begin{array}{l}\text { the preliminary } \\
\text { evaluation }\end{array}$ \\
\hline & $\begin{array}{l}\text { 2) Code of Conduct and Clean Government } \\
\text { Regulations for Environmental Impact } \\
\text { Assessment of Construction Projects }\end{array}$ & the legal liability \\
\hline $\begin{array}{l}\text { Law on } \\
\text { Prevention } \\
\text { and Control } \\
\text { of Water }\end{array}$ & $\begin{array}{l}\text { 1) Implemental Regulations for Law on Prevention } \\
\text { and Control of Water Pollution }\end{array}$ & $\begin{array}{l}\text { the river chief } \\
\text { system; the } \\
\text { registration of } \\
\text { pollutant discharge; } \\
\text { the legal liability }\end{array}$ \\
\hline Pollution & $\begin{array}{l}\text { 2) Regulations on the Prevention and } \\
\text { Control of Pollution from drinkable water } \\
\text { Source Protection Areas }\end{array}$ & $\begin{array}{l}\text { the standards of } \\
\text { drinkable water } \\
\text { source protection }\end{array}$ \\
\hline \multirow{4}{*}{$\begin{array}{c}\text { Law on } \\
\text { Prevention } \\
\text { and Control } \\
\text { of Water } \\
\text { Pollution }\end{array}$} & $\begin{array}{l}\text { 1) Regulations on the Supervision and } \\
\text { Administration of Sewage outfall to Rivers. }\end{array}$ & $\begin{array}{l}\text { the discharge of } \\
\text { sewage into rivers }\end{array}$ \\
\hline & $\begin{array}{l}\text { 2) Regulations on the Management of Ozone } \\
\text { Depleting Substances }\end{array}$ & $\begin{array}{l}\text { the administrative } \\
\text { penalties }\end{array}$ \\
\hline & $\begin{array}{l}\text { 3) Measure for Automatic Monitoring and } \\
\text { Management of Pollution Sources }\end{array}$ & $\begin{array}{l}\text { the administrative } \\
\text { penalties }\end{array}$ \\
\hline & 4) Measure for the Supervision of Coal Business & $\begin{array}{l}\text { the administrative } \\
\text { penalties }\end{array}$ \\
\hline $\begin{array}{l}\text { Law on the } \\
\text { Prevention } \\
\text { and Control of }\end{array}$ & $\begin{array}{l}\text { 1) Regulations on the Administration of } \\
\text { Recycling and Disposal of Waste Electrical and } \\
\text { Electronic Products }\end{array}$ & $\begin{array}{l}\text { the mandatory } \\
\text { recycling }\end{array}$ \\
\hline Environment & & the subjects of the \\
\hline $\begin{array}{l}\text { Pollution } \\
\text { Caused by } \\
\text { Solid Wastes }\end{array}$ & $\begin{array}{l}\text { 2) Measure for the Management of Hazardous Waste } \\
\text { Business Licenses. }\end{array}$ & $\begin{array}{l}\text { license related to } \\
\text { hazardous waste } \\
\text { recycling business }\end{array}$ \\
\hline
\end{tabular}


of Pollutants for Onshore Petroleum Exploitation and Production Industry, etc. On the other hand, Environmental Protection Law, Law on the Prevention and Control of Atmospheric Pollution, and Law on the Prevention and Control of Environmental Pollution by Solid Waste have made stricter and more comprehensive provisions on chemical environmental protection.

3) Management Measure for Environmental Protection of Electromagnetic Radiation. The administrative rule was issued on 25 March, 1997. The primary legal conflict is that the fourth chapter of the Management Measures only imposes penalties on the relevant illegal activities of organizations and individuals, such as penalty of not more than $30,000 \mathrm{RMB}$ yuan, correction in particular time, and suspension of production or operation. However, in order to meet the requirements for ecological civilization construction, Environmental Protection Law has expanded the types of punishment for environmental violations and increased the upper limit of penalties. In accordance with the Law, the Management Measures should be revised to increase the types of penalty for illegal activities such as restriction of production, suspension of production for renovation, and to increase the upper limit of penalties.

4) Measure for the Procedures of the Legislation of Environmental Administrative Rules. The administrative rule was issued on 11 April, 2005. The primary legal conflict is that according to Article 13 of the Measure, Environmental administrative rules can set provisions that directly deprive citizens, legal persons, or other organizations of their vital interests. However, Article 80 of Legislation Law clearly stipulates that without the authorization of laws or administrative regulations, or the decisions and orders of the State Council, administrative rules shall not set provisions that impair the rights of citizens, legal persons, and other organizations or increase their obligations. Thus, it is proposed to abolish Article 13 of the Measure.

5) Interim Provisions on the Punishments against Environmental Violations and Disciplinary Actions. The administrative rule was issued by the Ministry of Supervision and the former State Environmental Protection Administration on 20 February, 2006. The primary legal conflict is that Article 68 of Environmental Protection Law stipulates the blame-taking resignation of the primary officials of the relevant departments responsible for the nine illegal acts, the punishment to the acts of tampering or forging the monitoring data, and the punishment to the violation of environmental information disclosure obligation. However, these provisions are too principled and their implementation relies on the related lower-level administrative rules. The Interim Provisions should be revised to provide more specific and implemental rules in accordance with the above provisions.

6) Measure for the Environmental Administrative Punishment. The Ministry of Environmental Protection issued the administrative rule on 30 December, 2009. The primary legal conflict is that the types of penalties stipulated in the Measure are inconsistent with the provisions of Chapter VI of Environmental Protection Law. The Measure did not provide restriction of production. Mean- 
while, the Measure provides many kinds of penalties, such as warning, seizure, revocation of licenses, and confiscation of illegal income, etc., which are not stipulated in the higher-level law. However, according to Article 12 of Administrative Compulsion Law, administrative rules can only formulate specific provisions within the limits of the acts subject to administrative penalty and the types and range of such penalty as prescribed by laws. Thus, those penalties in the Measure conflict with Administrative Compulsion Law.

\subsection{The Legal Conflicts between Law on Evaluation of Environmental Effects and the Relevant Administrative Regulations and Rules}

Law on Evaluation of Environmental Effects was revised on 2 July, 2016, and implemented as of 1 September, 2016. The article finds that two administrative rules conflict with the Law.

1) Measure for Environmental Protection Management of Traffic Construction Projects. The Ministry of Communications issued the administrative rule on 11 April, 2003. The primary legal conflict is that some provisions of the Measure conflict with Law on Evaluation of Environmental Effects. Articles 10, 11, and 13 of the Measure provide the preliminary evaluation of environmental impact by the traffic departments in charge. However, Article 22 of the Law has abolished the preliminary evaluation. Besides, Articles 8 and 11 of the Measure stipulate that the environmental effects registration form submitted by the construction entities shall be subject to audit and approval by the relevant departments. Nevertheless, Article 22 of the Law establishes a recordation administration of the environmental impact registration form to replace the previous approval system.

2) Code of Conduct and Clean Government Regulations for Environmental Impact Assessment of Construction Projects. The former General Administration of Environmental Protection issued the administrative rule on 2 November, 2005. The primary legal conflict is that the legal liability stipulated in Chapter IV of the Regulations conflicts with that in Law on Evaluation of Environmental Effects. For example, the administrative rule does not classify "failure to fulfill environmental evacuation obligations" as illegal activities. The responsibility subject stipulated by Article 14 of the Code is limited to the "evaluation institution", and the responsibility subject stipulated by Article 34 of Law on Evaluation of Environmental Effects is "the staff of the administrative department of environmental protection or any other department", and the latter has a broader scope.

\subsection{The Legal Conflicts between Law on Prevention and Control of Water Pollution and the Relevant Administrative Regulations and Rules}

Law on Prevention and Control of Water Pollution was revised on 27 June, 2017, and implemented from1 January, 2018. The article finds that one administrative regulation and two administrative rules conflict with the Law. 
1) Implemental Regulations for Law on Prevention and Control of Water Pollution. The State Council promulgated the administrative regulations on 20 March, 2000. The primary legal conflict is that it has been nearly 18 years since the promulgation of the Regulations, during which Law on Prevention and Control of Water Pollution has been revised many times. Therefore, the Regulations has severely lagged behind the Law. It is suggested that the implemental Regulations be revised systematically according to the Law. The first is to add specific and operational provisions on the river chief system and the centralized treatment of rural sewage to enhance the bearing capacity of environmental resources in river basins. The second is to abolish the provisions on the administrative license on water pollution prevention and control facilities and the registration of pollutant discharge. The third is to establish a pollutant discharge licensing system. The fourth is to strengthen the legal liability for illegal activities.

2) Regulations on the Prevention and Control of Pollution from drinkable water Source Protection Areas. The former State Environmental Protection Administration jointly promulgated the administrative rule, the former Ministry of Health, the former Ministry of Construction, Ministry of Water Resources, and the former Ministry of Geology and Minerals on 10 July, 1989, and revised on 22 December, 2010. The primary legal conflict is that the revised Law on Prevention and Control of Water Pollution has formulated new standards for the pollution prevention and management of drinkable water source protection areas. It is recommended that the Regulations be revised in accordance with Articles 69 to 72 and Article 79 of the revised Law on Prevention and Control of Water Pollution. Firstly, according to the higher-level law, it is suggested to establish and specify an investigation and evaluation system for drinkable water source areas. Secondly, it should be stipulated that the drinkable water suppliers have legal responsibility for drinkable water quality. The third is to provide specific provisions for the construction of emergency or standby water sources and emergency plans for drinkable water safety.

3) Regulations on the Supervision and Administration of Sewage outfall to Rivers. Ministry of Water Resources promulgated the administrative rule on 30 November, 2004, and revised on 16 December, 2015. The primary legal conflict is that Law on Prevention and Control of Water Pollution has updated the relevant provisions on the discharge of sewage into rivers. It is suggested that according to Articles 5 and 16 of Law on Prevention and Control of Water Pollution and the Opinions on the Comprehensive Implementation of River Chief System issued by General Office of the CPC Central Committee and the General Office of the State Council in 2016, the responsibility of river chief for the supervision of pollutant discharge to rivers should be established, and the total amount control system for pollutant discharge should be set up according to the carrying capacity of the environmental resources of rivers, so as to optimize the layout of outfalls to rivers and lakes in the prevention and control planning on water pollution of rivers. 


\subsection{The Legal Conflicts between Law on the Prevention and Control of Atmospheric Pollution and the Relevant Administrative Regulations and Rules}

Law on the Prevention and Control of Atmospheric Pollution was revised on 27 June, 2017, and implemented from 1January, 2018. The article finds that one administrative regulations and two administrative rules conflict with the Law.

1) Regulations on the Management of Ozone Depleting Substances. The State Council passed the administrative regulations on 24 March, 2010. The primary legal conflict is that the administrative penalties stipulated in Law on the Prevention and Control of Atmospheric Pollution is inconsistent with that stipulated in the Regulations. The Law stipulates that the competent department of ecology and environment of the people's government at or above the county level shall impose a fine of not less than 100,000 RMB yuan but not more than one million RMB yuan if an enterprise has discharged atmospheric pollutants without lawfully obtaining a pollutant discharge license. However, according to Articles 32 and 33 of the Regulations, the upper limit of the fine on the illegal activity is only 500,000 RMB yuan, only half of that set up by the higher-level law. Moreover, the types of administrative penalty stipulated in the Regulations are also less than the Law. According to the Regulations, the government can only impose six kinds of administrative penalties on the enterprises that conduct related illegal activities, including fine, order for correction, confiscation of illegal proceeds, verification and reduction of quota, certificate revocation, and demolishing illegal equipment. However, the Law also stipulates three administrative penalties for severe illegal acts, including administrative detention, ordering production suspension for rectification, and ordering business to stop operations or close down.

2) Measure for Automatic Monitoring and Management of Pollution Sources. The General Administration of Environmental Protection promulgated the administrative rule on 7 July, 2005. The primary legal conflict is that the administrative penalties stipulated in the Measure are inconsistent with those stipulated in the revised Law on the Prevention and Control of Atmospheric Pollution and the revised Law on Prevention and Control of Water Pollution. According to the Measure, the competent department of ecology and environment of the people's government at or above the county level can impose a fine of not more than 100,000 RMB yuan if an enterprise fails to install automatic monitoring equipment and its supporting facilities. However, according to Article 82 of Law on the Prevention and Control of Water Pollution and Article 100 of Law on the Prevention and Control of Atmospheric Pollution, if an enterprise failed to install or use automatic equipment for monitoring pollutant discharge, or misappropriated, destroyed, or moved or altered without approval any environment quality monitoring equipment, the competent department of ecology and environment of the people's government at or above the county level shall impose a fine of not less than 20,000 RMB yuan but not more than 200,000 RMB yuan. 
The upper limit of fine in the Laws is twice higher than that in the Measure.

3) Measure for the Supervision of Coal Business. The National Development and Reform Commission promulgated the administrative rule on 30 July, 2014. The primary legal conflict is that the types of administrative penalties and the amount of the fine provided in the Measure are inconsistent with those provided in the Law. According to Article 27 of the Measure, if an enterprise failed to take necessary measures in the process of loading, unloading, storing, processing and transporting coal and caused environmental pollution around it, the competent department of ecology and environment of the people's government at or above the county level shall order it to make corrections within a certain period. If it failed to make corrections within the required period, it shall be included in the list of violations and dishonesty and made public. However, according to Articles 116 and 117 of Law on the Prevention and Control of Atmospheric Pollution, in addition to the administrative penalties mentioned above, the competent department of ecology and environment can choose to impose fines, ban vehicles from driving, or order it to shut down or stop its business operations for rectifications. Article 28 of the Measure stipulates that those who sell or import unqualified coal shall be ordered to make corrections within a certain period, and those who failed to do that shall be included in the list of violations and dishonesty and made public. While, in accordance with Articles 103 and 104 of Law on the Prevention and Control of Atmospheric Pollution, in addition to the administrative penalties mentioned above, the competent department of ecology and environment can choose to order the violator to make a correction, confiscate the raw materials, products, and illegal proceeds, and impose a fine of not less than one time but not more than three times the monetary value of the things in question. It is suggested that the Measure shall be revised to add the types of administrative penalties and increase the number of fines in accordance with the relevant provisions of Law on the Prevention and Control of Atmospheric Pollution.

\subsection{The Legal Conflicts between Law on the Prevention and Control of Environment Pollution Caused by Solid Wastes and the Relevant Administrative Regulations and Rules}

Law on the Prevention and Control of Environment Pollution Caused by Solid Wastes was revised and passed on 7 November, 2016, and implemented from the same day. The article finds that two administrative regulations conflict with the Law.

1) Regulations on the Administration of Recycling and Disposal of Waste Electrical and Electronic Products. The State Council passed the administrative regulations on 20 August, 2008. The primary legal conflict is that the Law provides mandatory recycling, while the Regulations does not. The primary legal conflict is that Paragraph 2, Article 18 of Law on the Prevention and Control of Environment Pollution Caused by Solid Wastes, the enterprises producing, selling or importing products and packages that have been listed in the catalog sub- 
ject to mandatory recycling shall reclaim the products and packages according to the relevant provisions. It is suggested that the Regulations be revised in accordance with the relevant provisions of the Law to conduct the mandatory recycling of waste electrical and electronic products.

2) Measure for the Management of Hazardous Waste Business Licenses. The administrative regulations was revised by the State Council on 6 February, 2016. The main legal conflict between the Measure and Law on the Prevention and Control of Environment Pollution is that, the subjects of the license related to hazardous waste recycling business are inconsistent. Article 2 of the Measure stipulates that entities engaged in the collection, storage and disposal of hazardous wastes shall apply for business licenses. In contrast, Article 57 of the Law stipulates that, in addition to the above-mentioned entities, entities engaged in businesses of utilizing hazardous wastes shall also apply for business licenses.

\section{The Legislative Vacancies and the Legislative Lags of Local Environmental Laws}

China has a vast territory and obvious environmental differences. Therefore, the national environmental laws are more principled and lack maneuverability at province and city levels. Moreover, it is difficult to balance the differences in the environment of each region. Therefore, local environmental decrees and rules are designed as supplementary regulations and specific rules for the enforcement of national environmental laws and administrative regulations. National environmental laws and local environmental laws need to coordinate with each other to establish an effective legal system for ecological civilization construction. For example, many environmental laws state clearly that the local government should take responsibility for local environmental quality, but it is a pity that those clues usually exist in name only and could not be implemented very well because that those clause cannot be operational with the blanket of the specific legal liability mechanism in local laws (Sun, 2008). Since the $18^{\text {th }}$ National Congress of the CPC, several national environmental laws have been revised and stipulated stricter environmental protection standards and legal liabilities. However, severe legislative lags occur that a large number of local environmental laws have not been revised timely in accordance with the higher-level laws. In addition, many supporting rules and regulations were promulgated too slowly after the higher-level laws' enforcement, waiting a long time instead of simultaneously being implemented with the law. Those legislative lags were apparently not conducive to its functioning well, severely damaging China's environmental legal system (Sun, 2008).

Taking 19 national environmental laws, administrative regulations and their implemental local laws as examples, this article illustrates the legislative vacancies and the legislative lags in local environmental laws. The reason for choosing the examples is that those 19 laws and administrative regulations are more principled and lacking operability, and besides, they all rely on the lower-level and 
specific implemental local laws to achieve their legislative purposes. As of 1 October, 2018, the legislative vacancies and the legislative lags of the implemental local laws in 31 provincial-level administrative regions excluding Hong Kong, Macau and Taiwan and 49 major cities with legislative power are shown in Table 6. What needs to be pointed out is that, according to Legislation Law, a major city refers to a city where the People's Government of the province or autonomous region is seated, the city where a special economic zone is located, and any other major city approved by the State Council.

\subsection{The Legislative Vacancies and the Legislative Lags of the Implemental Local Laws of the Environmental Comprehensive Laws and Administrative Regulations}

The environmental comprehensive laws and administrative regulations mainly include Environmental Protection Law, Law on Evaluation of Environmental Effects, Regulations on the Administration of City Appearance and Environmental Sanitation.

1) Environmental Protection Law. There are 63 implemental local laws for the Law. The legislative bodies of 29 provincial administrative regions and 34 major cities have promulgated implemental local laws in accordance with the Law, with legislative vacancy rates of $6.5 \%$ and $30.6 \%$, respectively. Among them, 21 (67.7\%) provincial administrative regions lag their legislation behind the revised Environmental Protection Law, with an average legislative lag of 2415 days.

2) Law on Evaluation of Environmental Effects. There are 4 implemental local laws of the Law. The legislative bodies of 4 provincial administrative regions have promulgated implemental local laws in accordance with the Law, with a legislative vacancy rate of $12.9 \%$. None of the major cities has enacted the implemental local laws. All of the provincial administrative regions lag their legislation behind the revised Law on Evaluation of Environmental Effects, with an average legislative lag of 2134 days.

3) Regulations on the Administration of City Appearance and Environmental Sanitation. There are 72 implemental local laws of the Regulations. The legislative bodies of 26 provincial administrative regions and 46 major cities have promulgated implemental local laws in accordance with the Regulations, with legislative vacancy rates of $16.1 \%$ and $6.1 \%$, respectively. Among them, 81 (53.3\%) have lagged behind the revised Environmental Protection Law, with an average legislative lag of 2415 days.

\subsection{The Legislative Vacancies and the Legislative Lags of the Implemental Local Laws of the Water Resources and Marine Environmental Protection Laws}

The water resources and marine environmental protection laws mainly include Water Law, Law on Prevention and Control of Water Pollution, Marine Environmental Protection Law and Fisheries Law.

1) Water Law. There are 60 implemental local laws of the Law. The legislative 
Table 6. The legislative vacancies and the legislative lags of the implemental local laws.

\begin{tabular}{|c|c|c|c|c|}
\hline $\begin{array}{c}\text { Laws and Administrative } \\
\text { Regulations }\end{array}$ & $\begin{array}{c}\text { Legislative } \\
\text { vacancy rate of } \\
\text { provincial-level } \\
\text { region* }\end{array}$ & $\begin{array}{l}\text { Legislative } \\
\text { vacancyrate } \\
\text { of major } \\
\text { city }^{* *}\end{array}$ & $\begin{array}{l}\text { Legislative } \\
\text { Lag } \\
\text { Rate }^{\star * \star}\end{array}$ & $\begin{array}{l}\text { Average } \\
\text { Lag } \\
\text { (Day) }\end{array}$ \\
\hline 1) Environmental Protection Law & $6.5 \%$ & $30.6 \%$ & $67.7 \%$ & 2415 \\
\hline $\begin{array}{l}\text { 2) Law on Evaluation of } \\
\text { Environmental Effects }\end{array}$ & $87.1 \%$ & $100 \%$ & $100 \%$ & 2134 \\
\hline $\begin{array}{l}\text { 3) Regulations on the Urban } \\
\text { Appearance and Environmental } \\
\text { Hygiene Management }\end{array}$ & $16.1 \%$ & $6.1 \%$ & $53.3 \%$ & 2678 \\
\hline 4) Water Law & $3.2 \%$ & $38.8 \%$ & $93.3 \%$ & 2960 \\
\hline $\begin{array}{l}\text { 5) Law on Prevention and Control } \\
\text { of Water Pollution }\end{array}$ & $45.2 \%$ & $73.5 \%$ & $76.7 \%$ & 4559 \\
\hline $\begin{array}{l}\text { 6) Marine Environmental } \\
\text { Protection Law }\end{array}$ & $9.1 \%$ & $33.3 \%$ & $100 \%$ & 1585 \\
\hline 7) Fisheries Law & $6.9 \%$ & $79.6 \%$ & $89.7 \%$ & 2571 \\
\hline $\begin{array}{l}\text { 8) Law on the Prevention and } \\
\text { Control of Atmospheric Pollution }\end{array}$ & $41.9 \%$ & $20.4 \%$ & $88.9 \%$ & 2615 \\
\hline $\begin{array}{l}\text { 9) Law on the Prevention and } \\
\text { Control of Environmental } \\
\text { Pollution by Solid Waste }\end{array}$ & $41.9 \%$ & $20.4 \%$ & $80.4 \%$ & 2515 \\
\hline $\begin{array}{l}\text { 10) Law on Prevention and } \\
\text { Control of Pollution from } \\
\text { Environmental Noise }\end{array}$ & $77.4 \%$ & $53.1 \%$ 。 & $19.5 \%$ & 2120 \\
\hline 11) Forest Law & $9.7 \%$ & $24.5 \%$ & $46.2 \%$ & 3064 \\
\hline 12) Grassland Law & $61.3 \%$ & $98 \%$ & $67.34 \%$ & 3521 \\
\hline $\begin{array}{l}\text { 13) Law on Water and Soil } \\
\text { Conservation }\end{array}$ & $3.2 \%$ & $85.7 \%$ & $37.5 \%$ & 3460 \\
\hline $\begin{array}{l}\text { 14) Law on the Protection of } \\
\text { Wild Life }\end{array}$ & $6.5 \%$ & $87.8 \%$ & $100 \%$ & 3765 \\
\hline $\begin{array}{l}\text { 15) Regulations on Nature } \\
\text { Reserves }\end{array}$ & $6.5 \%$ & $87.8 \%$ & $100 \%$ & 3765 \\
\hline $\begin{array}{l}\text { 16) Regulations on Scenic and } \\
\text { Historic Areas }\end{array}$ & $32.2 \%$ & $55.1 \%$ & $23.9 \%$ & 1829 \\
\hline 17) Law on Energy Conservation & $3.2 \%$ & $71.4 \%$ & $100 \%$ & 2442.71 \\
\hline $\begin{array}{l}\text { 18) Regulations on Energy } \\
\text { Conservation in Public Institutions }\end{array}$ & $25.8 \%$ & $91.8 \%$ & 0 & 0 \\
\hline $\begin{array}{l}\text { 19) Regulations on Energy } \\
\text { Conservation of Civil Buildings }\end{array}$ & $45.2 \%$ & $69.4 \%$ & $9.4 \%$ & 410 \\
\hline Average & $27.8 \%$ & $59.7 \%$ & $66.0 \%$ & 2547.8 \\
\hline
\end{tabular}

${ }^{\star}$ Legislative vacancy rate of provincial-level region $=$ the number of provincial administrative regions without implemental local laws of higher-level laws $\div 31 \times 100 \%$; ${ }^{* *}$ Legislative vacancy rate of major city $=$ the number of major cities without implemental local laws of higher-level laws $\div 49 \times 100 \%$; ${ }^{* *}$ Legislative Lag Rate $=$ number of lagged local laws $\div$ number of local laws $\times 100 \%$. 
bodies of 30 provincial administrative regions and 30 major cities have promulgated implemental local laws in accordance with the Law, with legislative vacancy rates of $3.2 \%$ and $38.8 \%$, respectively. Among them, 56 (93.3\%) have lagged behind the revised Water Law, with an average legislative lag of 2960 days.

2) Law on Prevention and Control of Water Pollution. There are 30 implemental local laws of the Law. The legislative bodies of 17 provincial administrative regions and 13 major cities have promulgated implemental local laws in accordance with the Law, with legislative vacancy rates of $45.2 \%$ and $73.5 \%$, respectively. Among them, 46 (76.7\%) have lagged behind the revised Law on Prevention and Control of Water Pollution, with an average legislative lag of 4559 days.

3) Marine Environmental Protection Law. There are 30 implemental local laws of the Law. 10 of the 11 coastal provincial administrative regions and 8 of the 12 coastal major cities have enacted implemental local laws in accordance with the Law, with legislative vacancy rates of $9.1 \%$ and $33.3 \%$, respectively. All of them have lagged behind the revised Marine Environmental Protection Law, with an average legislative lag of 4559 days.

4) Fisheries Law. There are 39 implemental local laws of the Law. The legislative bodies of 29 provincial administrative regions and 10 major cities have promulgated implemental local laws in accordance with the Law, with legislative vacancy rates of $6.9 \%$ and $79.6 \%$, respectively. Among them, $35(89.7 \%)$ have lagged behind the revised Fisheries Law, with an average legislative lag of 2571 days.

\subsection{The Legislative Vacancies and the Legislative Lags of the Implemental Local Laws of the Atmospheric, Solid, Noise Pollution Prevention and Control Laws}

The atmospheric, solid, noise pollution prevention and control laws mainly include Law on the Prevention and Control of Atmospheric Pollution, Law on the Prevention and Control of Environmental Pollution by Solid Waste and Law on Prevention and Control of Pollution from Environmental Noise.

1) Law on the Prevention and Control of Atmospheric Pollution. There are 45 implemental local laws of the Law. The legislative bodies of 20 provincial administrative regions and 25 major cities have promulgated implemental local laws in accordance with the Law, with legislative vacancy rates of $35.5 \%$ and $49 \%$, respectively. Among them, 40 (88.9\%) have lagged behind the final revision of the Law, with an average legislative lag of 2615 days.

2) Law on the Prevention and Control of Environmental Pollution by Solid Waste. There are 45 implemental local laws of the Law. The legislative bodies of 18 provincial administrative regions and 39 major cities have promulgated implemental local laws in accordance with the Law, with legislative vacancy rates of $41.9 \%$ and $20.4 \%$, respectively. Among them, 41 (80.4\%) have lagged behind the final revision of the $L a w$, with an average legislative lag of 2515 days.

3) Law on Prevention and Control of Pollution from Environmental Noise. 
There are 30 implemental local laws of the Law. The legislative bodies of 7 provincial administrative regions and 23 major cities have promulgated implemental local laws in accordance with the $L a w$, with legislative vacancy rates of $77.4 \%$ and $53.1 \%$, respectively. Among them, 8 (19.5\%) have lagged behind the final revision of the $L a w$, with an average legislative lag of 2120 days.

\subsection{The Legislative Vacancies and the Legislative Lags of the Implemental Local Laws of the Protection of Forest, Grassland and Soil and Water Environmental Protection Laws}

The protection of forest, grassland and soil, and water environmental protection laws mainly include Forest Law, Grassland Law and Law on Water and Soil Conservation.

1) Forest Law. There are 65 implemental local laws of the law. The legislative bodies of 28 provincial administrative regions and 37 major cities have promulgated implemental local laws in accordance with the Law, with legislative vacancy rates of $9.7 \%$ and $24.5 \%$, respectively. Among them, 36 (46.2\%) have lagged behind the final revision of the Law, with an average legislative lag of 3064 days.

2) Grassland Law. There are 13 implemental local laws of the Law. The legislative bodies of 12 provincial administrative regions and 1 major city have promulgated implemental local laws in accordance with the Law, with legislative vacancy rates of $61.3 \%$ and $98 \%$, respectively. Among them, 31 (67.3\%) have lagged behind the final revision of the Law, with an average legislative lag of 3521 days.

3) Law on Water and Soil Conservation. There are 37 implemental local laws of the Law. The legislative bodies of 30 provincial administrative regions and 7 major cities have promulgated implemental local laws in accordance with the Law, with legislative vacancy rates of $3.2 \%$ and $85.7 \%$, respectively. Among them, 24 (37.5\%) have lagged behind the final revision of the Law, with an average legislative lag of 3460 days.

\subsection{The Legislative Vacancies and the Legislative Lags of the Implemental Local Laws of the Wildlife Conservation, Nature Reserves, Scenic Spots Protection Laws and Administrative Regulations}

The wildlife conservation, nature reserves, scenic spots protection laws and administrative regulations mainly include Law on the Protection of Wild Life, Regulations on Nature Reserves and Regulations on Scenic and Historic Areas.

1) Law on the Protection of Wild Life. There are 35 implemental local laws of the Law. The legislative bodies of 29 provincial administrative regions and 6 major cities have promulgated implemental local laws in accordance with the $L a w$, with legislative vacancy rates of $6.5 \%$ and $87.8 \%$, respectively. All of them have lagged behind the final revision of the Law, with an average legislative lag of 3765 days.

2) Regulations on Nature Reserves. There are 33 implemental local laws of the 
Regulations. The legislative bodies of 24 provincial administrative regions and 9 major cities have promulgated implemental local laws in accordance with the Regulations, with legislative vacancy rates of $22.6 \%$ and $81.6 \%$, respectively. Among them, 58 (72.5\%) have lagged behind the final revision of the Regulations, with an average legislative lag of 2583 days.

3) Regulations on Scenic and Historic Areas. There are 43 implemental local laws of the Regulations. The legislative bodies of 21 provincial administrative regions and 22 major cities have promulgated implemental local laws in accordance with the Regulations, with legislative vacancy rates of $32.2 \%$ and $55.1 \%$, respectively. Among them, 21 (23.9\%) have lagged behind the final revision of the Regulations, with an average legislative lag of 1829 days.

\subsection{The Legislative Vacancies and the Legislative Lags of the Implemental Local Laws of the Energy Conservation and Cleaner Production Laws and Administrative Regulations}

The energy conservation and cleaner production laws and administrative regulations mainly include Law on Energy Conservation, Energy Conservation Regulations for State-funded Institutions, Energy Conservation Regulations for State-funded Institutions and Regulations on Energy Conservation in Civil Buildings.

1) Law on Energy Conservation. There are 44 implemental local laws of the Law. The legislative bodies of 30 provincial administrative regions and 14 major cities have promulgated implemental local laws in accordance with the Law, with legislative vacancy rates of $3.2 \%$ and $71.4 \%$, respectively. All of them have lagged behind the final revision of the Law, with an average legislative lag of 2443 days.

2) Energy Conservation Regulations for State-funded Institutions. There are 27 implemental local laws of the Regulations. The legislative bodies of 23 provincial administrative regions and 4 major cities have promulgated implemental local laws in accordance with the Regulations, with legislative vacancy rates of $25.8 \%$ and $91.8 \%$, respectively. None of them has lagged behind the final revision of the Regulations.

3) Regulations on Energy Conservation in Civil Buildings. There are 32 implemental local laws of the Regulations. The legislative bodies of 17 provincial administrative regions and 15 major cities have promulgated implemental local laws in accordance with the Regulations, with legislative vacancy rates of $45.2 \%$ and $69.4 \%$, respectively. All of them have lagged behind the final revision of the Regulations, with an average legislative lag of 410 days.

\section{The Legal Conflicts between Local Environmental Protection Legislation and the Higher-Level Laws}

The principle that local laws must not conflict with the higher-level laws are one of the most important principles of Legislation Law. According to the first paragraph of Article 72 and the first paragraph of Article 82, the legislature of a province, autonomous region, municipality directly under the central govern- 
ment may enact local decrees and rules provided that they shall not contravene any provision of the Chinese Constitution, national laws and administrative regulations. According to the second paragraph of Article 72 and the second paragraph of Article 82, the legislature in a city with districts may enact local decrees and rules related to urban and rural development and administration, environmental protection, and historical culture protection, if they shall not contravene any provision of the Chinese Constitution, national laws, administrative regulations and the local decrees in force in the province or autonomous region in which the city is located.

Specifically, the principle of non-conflict includes three sub-principles. Firstly, local environmental laws must not conflict with the specific provisions of the Chinese Constitution, national laws, and administrative regulations. Secondly, local laws must not conflict with the guiding ideology, legislative purposes, basic principles and legislative spirit of the Chinese Constitution, national laws, and administrative regulations. Thirdly, local environmental laws may not stipulate legal reservation matters that should be stipulated by the national laws such as Environmental Protection Law, Criminal Law, Law on Administrative Penalty, etc.

In principle, even if local environmental laws have not been revised, the national environmental laws should be given priority if there is a conflict between the two. However, due to the prevalence of local protectionism, many local courts do not apply the conflict rules of the higher-level laws and lower-level laws in the trial. On the contrary, when the lower law conflicts with the higher law, applying the lower law is usually preferred in reality (Huang, 2016). For example, in April 1999, the General Office of the Standing Committee of the Fujian Provincial People's Congress submitted to the Higher People's Court of Fujian Province the Opinions on Correcting the Unappropriated Approval of Sanming Intermediate People's Court according to Law to apply the lower-level law (Zeng \& Huang, 1997). In the Seed Case of Luoyang Intermediate People's Court in 2003, the judge confirmed that there was a conflict between Regulations on Crop Seed Management of Henan Province and Seed Law, and applied Seed Law, which led to the intervention of the Standing Committee of Henan Provincial People's Congress. The Standing Committee believed that the lower-level Regulations should be applied and that what the judge did was actually an illegal judicial review of local decrees (Anonymous, 2004). In view of this, the unity of national environmental laws and local environmental laws has become a prominent problem that damages China's environmental legal system.

Through the analysis of 2908 environment-related local decrees, local rules, autonomous decrees and special decrees, it is found in this study that there are serious conflicts between local environmental laws and national environmental laws.

\subsection{The Prohibitions and Restrictions of the Higher-Level Laws Are Relaxed by the Lower-Level Laws}

Due to local protectionism and the priority for economic growth, some local en- 
vironmental laws may allow the eco-unfriendly behaviors that are actually prohibited or restricted by the higher-level environmental laws, so that the legislative objectives of the national laws cannot be realized.

Taking Qinghai province as an example, by comparenational environmental laws, with the local laws such as Regulations on the Protection of Drinkable Water Sources in Qinghai Province, Measure for Implementing Law on the Prevention and Control of Atmospheric Pollution in Qinghai Province, and Measure for Implementing Law on Soil and Water Conservation in Qinghai Province, etc., it is found that the local environmental laws in Qinghai province have the following three main problems. Firstly, the local laws permit the eco-unfriendly behaviors that are prohibited by the higher-level laws. Secondly, the local laws delete some of the prohibited emission types listed in the higher-level laws. Thirdly, local environmental laws fail to specify the prohibitive provisions of the higher-level laws according to local characteristics.

Local environmental laws in Hainan province, Liaoning province, and Hebei province also have this problem. For example, if construction projects have discharged pollutants in a Grade II drinkable water source reserve, whether or not they meet sewage standards, the people's government at or above the county level shall order their demolition or closure. However, Regulations on Ecological Environment Protection of Songtao Reservoir in Hainan Province and Regulations on Ecological Environment Protection of Nandu River in Hainan Province stipulate that as long as the pollutants discharged by the construction projects meet the sewage standard, they can be retained in the reserve. According to Articles 26 and 27 of Regulations on Scenic and Historic Areas, a scenic and historic area shall prohibit activities including cutting into a mountain, opening a quarry or mine, opening up wasteland, building a tomb or tombstone, or conducting any other activity that would destroy the landscape, vegetation or landforms; and in the core area of a scenic and historic area, any hotel, guest house, training center, sanitarium or other buildings not related to protection of the scenic and historic resources are prohibited. However, Administrative Measures for the Scenic Area of Qipan Mountain in Shenyang City, Regulations on the Scenic Spots in Dalian and Regulations on the Management of the Princes River Scenic Area in Benxi City ignore the provisions on the prohibition set in the higher-level laws and allow the above activities.

\subsection{The Lower-Level Laws Expand the Scope of Administrative Licenses Set Up by the Higher-Level Law}

For example, according to Article 44 of Environmental Protection Law, in nationwide, whether the pollution is serious or not, the total discharge volume control system to key pollutants shall be applied; and for areas whose indicators of key pollutants exceed the total discharge volume control or fail to achieve the environmental quality objectives determined by the central government, the environmental protection administrative departments at and above the provincial 
level shall suspend the procedures for approving the environmental impact assessment documents on construction projects in such areas that will increase the total discharge volume of key pollutants. Compared with the above provisions, Hubei Environmental Protection Regulations, on the one hand, narrows the geographical scope of the total discharge volume control system, and confines it to the areas with high industrial concentration and large amount of pollutant discharge. On the other hand, the Regulations establish the so-called temporary discharge licenses for enterprises whose discharge exceeds the permitted scope. However, the license has no basis of any higher-level law and obviously contradicts Article 45 of Environmental Protection Law that those without a pollutant discharge license may not discharge pollutants.

\subsection{Inconsistency of Legal Liabilities}

The legal liabilities stipulated by local environmental laws are inconsistent with those stipulated by higher-level laws.

Firstly, some local environmental laws reduce the penalties for environmental violations. Taking the penalties on water pollution accident as an example, comparing the Regulations on Prevention and Control of Water Pollution in Hubei Province with Law on Prevention and Control of Water Pollution, it is found that the former's fine is $30 \%$ or more of the income obtained in the previous year and that the fine of the latter is $20 \%$ or $30 \%$ of the direct loss caused by the water pollution accident, which is obviously different from the former. In addition, according to Article 39 of Law on the Prevention and Control of Atmospheric Pollution, existing coal-fueled heat boilers that fail to meet the discharge standards shall be demolished within a certain period as specified by the local people's governments. However, according to Article 34 of Regulation on the Prevention and Control of Atmospheric Pollution in Hubei, in this case, enterprises are only required to pay a fine.

Secondly, some local environmental laws increase the punishment illegally. In accordance with Article 11, Paragraph 2, and Article 13, Paragraph 1, of Administrative Punishment Law, local legislatures may, within the limits of the acts subject to administrative penalty and the types and range of such penalty as prescribed by the higher-level laws, administrative regulations and local decrees, formulate specific provisions in the local decrees and rules they enact. However, administrative penalties set in the local laws have violated the provisions above at times. For example, Article 23 of the Standing Committee of the People's Congress of Hebei Province on the Promotion of the Comprehensive Utilization of Crop Straw and the Prohibition of Open Burning stipulates that those who burncrop straws illegally may be fined not less than $500 \mathrm{RMB}$ yuan but not more than 1500 yuan. However, Notice on the Prohibition of Open Burning of Crop Straws in Handan City stipulates that a fine of $500-2000$ RMB yuan shall be imposed on those who burn crop straws illegally. The fines of the latter exceed the upper limit of the former and violate the administrative penalty law. 
Thirdly, the legislative subjects of sewage discharge fees have been narrowed in local environmental laws. According to Article 43 of Environmental Protection Law, all enterprises, public institutions, and other businesses that discharge pollutants shall pay pollutant discharge fees. However, according to Article 17 of Environmental Protection Regulations in Hubei Province only enterprises and commercial households shall pay pollutant discharge fees.

\subsection{Imperfect Local Legislative Mechanism}

The Failure of local legislatures to establish perfect local legislation mechanism in accordance with the requirements of higher-level laws is an important reason for the legal conflict.

On the one hand, the functions of local people's congresses is insufficient and blurred. At present, almost all local people's congresses set up special committees on environmental matters to take charge of local environmental legislation. However, they lack sufficient professionals and the understanding of the actual situation of environmental protection, making them difficult to undertake the legislation alone. Therefore, local departments of ecology and environment often initiate local legislative bills instead of the environmental committees in reality. As a result, the local people's congresses gradually lost their leading role in local legislation, and their main responsibility is to solicit opinions from all parties. Moreover, the Lack of independence and professionalism of local people's congresses has made it difficult to coordinate the department of ecology and environment with environmental departments, which may delay the legislative process and even damage the scientific and impartial nature of the legislation.

On the other hand, there is a lack of a mechanism for public participation in local environmental laws. Environment concerns the well-being of every Chinese citizen. Therefore, local legislation should encourage public participation, so that the public can reasonably express their demands through legislative activities, and substantively participate in legislative process. However, public participation in local legislation is faced with the following problems. Firstly, the scope of public participation is narrow and limited to making comments on the drafts or bills. Secondly, the channels for participation are not smooth enough, and the feedback system is deficient. Thirdly, Legislation Law only stipulates the principle of public participation in local environmental laws, and many local legislatures have not yet established the specific participation mechanisms. The above problems lead to the low enthusiasm of public participation in environmental legislation. Hence, public opinions can hardly have a practical impact on local environmental laws.

\section{Suggestions and Conclusion}

At present, China's environmental legal system has severe legal conflicts, legislative lags and gaps. As mentioned in this study, at least 18 administrative regulations and rules conflict with the five recently-revised national environmental 
protection laws. The legislative vacancy rate of local environmental laws reaches $27.8 \%$ and $59.7 \%$ at province level and in the major cities, respectively. The legislative lags are found in $66 \%$ of local environmental laws, with an average lag of 2547.8 days. In addition, there are many legal conflicts between national environmental laws and local environmental laws. This article proposes the following suggestions to realize the inherent unity and harmony of the environmental legal system.

Firstly, comprehensively examine the lower-level environmental laws to maintain the consistency of the Chinese environmental legal system. It is recommended that the central ministries and commissions, local people's congresses and the governments jointly set up special inspection teams for examining the local environmental laws. These teams shall comprehensively examine the environmental administrative regulations, administrative rules, local decrees, and local rules, and timely propose to revise and abolish the lower-level laws that conflict with the higher-level laws. Considering that some ministries and local governments have also formulated a large number of environmental normative documents which are likely to be in conflict with laws, it is recommended that those normative documents be included in the scope of checks. The examination results and related suggestions shall be submitted to the legislative affairs commission of the NPC Standing Committee for filing. After the examination, it is recommended to establish a joint supervision mechanism which shall be led by the Standing Committee of the NPC, the Ministry of Justice and the Ministry of Ecological Environment.

Secondly, strengthen the leading role of local people's congresses in the environmental legislative process. Firstly, local people's congresses should regard strengthening the legislature of the NPC as the basis for improving the quality of legislation, strengthening the leading consciousness, improving the leading mechanism, enhancing the leading ability, and establishing and improving the working mechanisms for the initiation, drafting, feasibility study, evaluation, and deliberation, etc. Secondly, the Standing Committee of the NPC should strengthen the guidance for local legislatures and provide professional training. Thirdly, the local people's congresses should include environmental legislative items in the annual legislative work plan and five-year legislative plan of the region, improve the responsibility of legislative items, and clarify the division of responsibilities for legislative quality. Thirdly, local people's congresses should timely formulate environmental legislation plans according to the local needs, clarify the division of legislative responsibilities, and coordinate local environmental departments with other relevant departments in the legislative process. Fourthly, according to actual conditions, local legislatures should focus on the major problems that urgently need to be resolved by local environmental legislation.

Thirdly, improve the construction of the filing and review mechanism. The article suggests that the first is to strengthen the filing works of the Standing 
Committee of the NPC and the Ministry of Justice by increasing staff and strengthening professional training. The second is to improve the review mechanism. If a local bill deletes, increases or changes the prohibitions and restricts of higher-level laws, or if the administrative licenses, penalties, compulsory measures of a local law are inconsistent with those of higher-level laws, the local people's congresses and the local governments shall be required to explain the following matters when submitting local legislation for filing:

Fourthly, optimize the mechanisms for information disclosure and public participation. Public participation is an important basis for the quality of legislation. However, tensions within the existing system render the environmental functions of information disclosure uncertain, with serious potential consequences-weakened state legitimacy and a hobbled environment (Wang, 2018). Chapter V of Environmental Protection Law stipulates the information disclosure and public participation. It is suggested that local legislatures should enact specific laws on the public participation mechanism for initiating, drafting, feasibility study, review and post-legislative evaluation to effectively guarantee the authenticity, extensiveness and representativeness of the public participation in environmental legislation. At the same time, local environmental legislation should further expand the scope of environmental information disclosure, and standardize and facilitate the disclosure process. In addition, local environmental laws should make specific and operational provisions to strengthen the responsibility of environmental information disclosure by enterprises, to ensure the public's right to know, participate, supervise.

The environmental challenges in China today are immense, but so are the opportunities for environmental legislative improvement. This study presented a comprehensive analysis of the disharmony in the Chinese environmental legal system. While many researchers worked on the inconsistency in China's environmental legal system, none of them investigated the issue from a holistic perspective. The study is the first one to provide a comprehensive contextual analysis about the current legal conflicts, legislative vacancies and the legislative lags based on the Chinese current environmental legal system including 30 laws, 45 administrative regulations, 85 administrative rules, and 2908 local decrees, local rules, autonomous decrees and special decrees.

\section{Conflicts of Interest}

The author declares no conflicts of interest regarding the publication of this paper.

\section{References}

Anonymous (2014). Luoyang Intermediate People's Court Denied the Local Decrees. Work of Shandong People's Congress, 1, 51-52.

Bao, Q., Shao, M., \& Yang, D. L. (2013). Does Environmental Regulation Inhibit Pollution Emissions? Economic Research Journal, 48, 42-54.

Environmental Protection Department (2016). Announcement on the Publication of the 
list of Environmental Protection Department Rules in Force (No. 68). http://www.sohu.com/a/120990934_464092

EPI Team (2018). The 2018 Environmental Performance Index: The Score and Ranking for China. https://epi.envirocenter.yale.edu/epi-country-report/CHN

Feng, C. Y. (2016). Thoughts on the Status of Local Environmental Laws in China Since the Revision of Legislation Law. Legality Vision, 7, 164-165.

Guo, X. X., \& Huang, C. (2005). A Comparative Study of Local Environmental laws in China and Australia. Journal of Ocean University of China (Social Sciences), 6, 100-101.

Huang, J. R. (2016). The Application and Limitation of the Rules of Conflict of Higher-Level and Lower-Level Laws by Court. Global Law Review, 38, 20-35.

Jiang, H. B., \& Liang, F. (2008). The Status Quo and Legislative Improvement of Local Environmental Protection in Guangxi. Social Scientist, 4, 121-124.

Jin, H. (2011). A Study on the Status Quo and Countermeasures of Local Environmental Protection Legislation in Liaoning Province. Environmental Protection and Circular Economy, 31, 67-71.

Li, C. F. (2016). Opportunities and Challenges Faced by Local Environmental Laws after the Revision of Legislation Law. Tribune of Study, 32, 67-71.

Li, L. L., \& Sheng, D. (2018). Local Environmental Laws and Optimization of Industry Resource Allocation Efficiency in China's Manufacturing Industry. China Industrial Economics, 7, 136-154.

Li, Y. A. (2014). Study on the Local Environmental laws Model in Shanxi. Theory Research, 36, 60-61.

Li, Z. P. (2017). Analysis on the Development Trend of Local Environmental Laws-Taking Guangdong Environmental Laws as the Focus of Investigation. Local Legislation Journal, 2, 1-10.

Sun, Y. H. (2008). Basic Experiences and Problems of China's Environmental Laws from Reform and Opening-Up. Journal of China University of Geosciences, 8, 41-49.

The CPC (2017). Briefing on Eco-Environmental Problems of Qilian Mountain National Nature Reserve in Gansu Province. http://www.gov.cn/xinwen/2017-07/20/content_5212107.htm

Tian, H., Lv, Y. B., \& Zhu, Y. (2014). Research Report on the Scale, Triggering Factors and Trends of Mass Incidents. The Annual Report on China's Rule of Law, 12, 270-289.

Wan, J. X. (2018). An Empirical Analysis of Local Environmental Laws in Districted Cities. Journal of Henan University of Economics and Law, 33, 27-35.

Wang, A. (2018). Explaining Environmental Information Disclosure in China. Ecology Law Quarterly, 44, 865-924.

Wang, J. (2009). Thirty Years Rule of Environmental Law in China: Retrospect and Reassessment. Journal of China University of Geosciences, 9, 3-9.

Wang, J. C. (2014). A Comparative Study of the Legislation Ideas of Environmental Criminal Law in Major Countries. Journal of the Party School of CPC Changchun Municipal Committee, 5, 42-45.

Wang, P. P. (2009). A Comparative Study of Local Environmental Laws System between China and the United States. Legal System and Society, 28, 35-36.

Wang, X. H. (2010). A Quantitative Analysis of Provincial-Level Local Environmental Laws: A Case Study of Six Provinces in Central China. China Environment Management, 1, 16-18. 
Wang, Y., \& Wang, Q. C. (2018). A Summary of Local Ecological and Environmental Laws in Districted Cities of Shandong Province (pp. 22-24). Work of Shandong People's Congress, 10.

$\mathrm{Xu}$, G. D., \& Faure, M. (2016). Explaining the Failure of Environmental Law in China. Columbia Journal of Asian Law, 29, 1-95.

Yang, L. Y. (2010). The Status Quo, Problems and Countermeasures of Local Environmental Laws in Hebei Province. Journal of Hebei University of Science and Technology (Social Sciences), 10, 58-63.

Yang, Z. F. (2012). The Twenty-Ninth Lecture of the Standing Committee of the Eleventh National People's Congress: Several Issues on China's Environmental Legal System and Environmental Protection. http://roll.sohu.com/20121026/n355790686.shtml

Yuan, X. H. (2018). A Comparative Study of the Legislative Purposes of Environmental Information Disclosure between China and EU Governments. Theory Research, 1, 130-132.

Zang, C. (2015). Analysis on Local Environmental Laws in Jiangsu Province. Journal of Shanxi Institute of Energy, 28, 184-186.

Zeng, G. H., \& Huang, Z. M. (1997). Who Can Determine the Legality of Local Decrees? The Standing Committee of the Fujian Provincial People's Congress Has Supervised and Urged the Correction of an Improper Approval of the Sanming Intermediate People's Court. People's Political Scene, 7, 4-5.

Zeng, L. B. (2015). Discussion on Local Environmental laws in China. Legal System and Society, 31, 13-14.

Zhang, M. J., \& Liu, X. L. (2017). 2016 Annual Report on Mass Incidents in China. Advances in China Public Security, 1, 3-18.

Zhou, D. (2018). On the Feasible Way to Improve the Benefit of Environmental Laws: Rational Distribution of Environmental Laws Powers between Central and Local Governments. Local Legislation Journal, 3, 90-103. 